\title{
THE TAXONOMIC VALUE OF POLLEN SURFACE PATTERNS IN SOME AUSTRALIAN EPACRIS (EPACRIDACEAE)
}

\author{
by Yvonne Menadue and R.K. Crowden \\ (with one plate and two appendices)
}

\begin{abstract}
Pollen grains of most known species of Epacris in Australia were examined by scanning electron microscopy. There is a range of patterns of surface ornamentation present, based upon which the species can be grouped into two broad classes: (1) "smooth", in which the tectum is essentially intact but pitted and rugulate to varying degrees; (2) "warte", in which the pollen is intectate with a range of surface processes generally $>2 \mu \mathrm{m}$. The patterns are useful at the interspecific level to delimit certain taxa with morphological overlap.
\end{abstract}

Key Words: Epacris, Epacridaceae, Australia, pollen surface, taxonomy.

In BANKS, M.R. et al. (Eds), 1991 (31:iii): ASPECTS OF TASMANIAN BOTANY - A TRIBUTE TO WINIFRED CURTIS. Roy. Soc. Tasm. Hobart: 113-117. https://doi.org/10.26749/rstpp.124.2.113

\section{INTRODUCTION}

Matthews' study $(1965,1966)$ of pollen morphology in 25 species of Epacris demonstrated a range of ektexine sculpturing from which he grouped pollen into two main types and an intermediate class. In one group (nine species) the pollen surface appeared "smooth", with the tectum either intact (psilate) or with some degree of pitting (foveolate or fossulate). Pollen of Matthews' second group ( 14 species) was predominantly intectate, the surface appearing "warted" (gemmate, verrucate, clavate or baculate) due to the occurrence of a variety of raised processes $>2 \mu \mathrm{m}$. In the two intermediate species the pollen of E. acuminata was psilate in the polar and furrow regions, but elsewhere the surface was rugulate with raised processes c. $1 \mathrm{~mm}$, while in E. apculata, the ektexine was represented by verrucate-rugulate processes $<2 \mu \mathrm{m}$. In a more recent study, McGlone (1978) examined the two New Zealand species. The tectum of E. alpina had a dense pattern of verrucae, while that of $E$. pauciflora was foveolate.

As part of our revision of the genus Epacris we felt it desirable to re-examine ektexine ornamentation, because of its potential taxonomic usefulness and because the status of several species considered by Matthews is currently under review. One species, $E$. apiculata, is soon to be transferred to the genus Rupicola (I. Telford, pers. comm.). A number of additional taxa, including newly described species not studied by Matthews, are now investigated. There are 37 named species of Epacris in Australia, and we have examined the pollen of all of them except the rare E. sparsa. Several unnamed taxa currently under investigation also are included in our study.

\section{MATERIALS AND METHODS}

In his study, Matthews used high-power light microscopy following acetolysis pre-treatment of pollen grains. In this work we have examined untreated pollen by scanning electron microscopy (SEM). Pollen grains from several different flowers were taken from dried herbarium specimens or from fresh plant collections and mounted on aluminium stubs using double-stick tape. They were prepared for SEM by gold coating in a high vacuum evaporative coating unit to a maximum thickness of $20 \mu \mathrm{m}$. Some grains collapsed under this treatment, the extent of collapse varying for different species. It was necessary, therefore, to apply sufficient pollen to the stub to ensure that there was an adequate sample of intact grains available for examination. The specimens were examined using a Philips 505 SEM operated at $15 \mathrm{kV}$. As far as was practical, several specimens of each species were examined, representing different collection sites (appendix l). A single annotated voucher for each taxon has been lodged in the Tasmanian Herbarium (appendix 2), except E. hamiltonii the vouchers for which are in the National Herbarium of NSW. The full list of specimens examined is available from the authors.

\section{RESULTS}

On the basis of their surface ornamentation, the pollens have been classed into two types, warted (16 taxa) and smooth (27 taxa) (appendix 1). However, within both these groups a range of variation is evident. the surface of smooth grains may show varying degrees of tectum pitting. Relatively minor pitting occurs in E. calvertiana, 

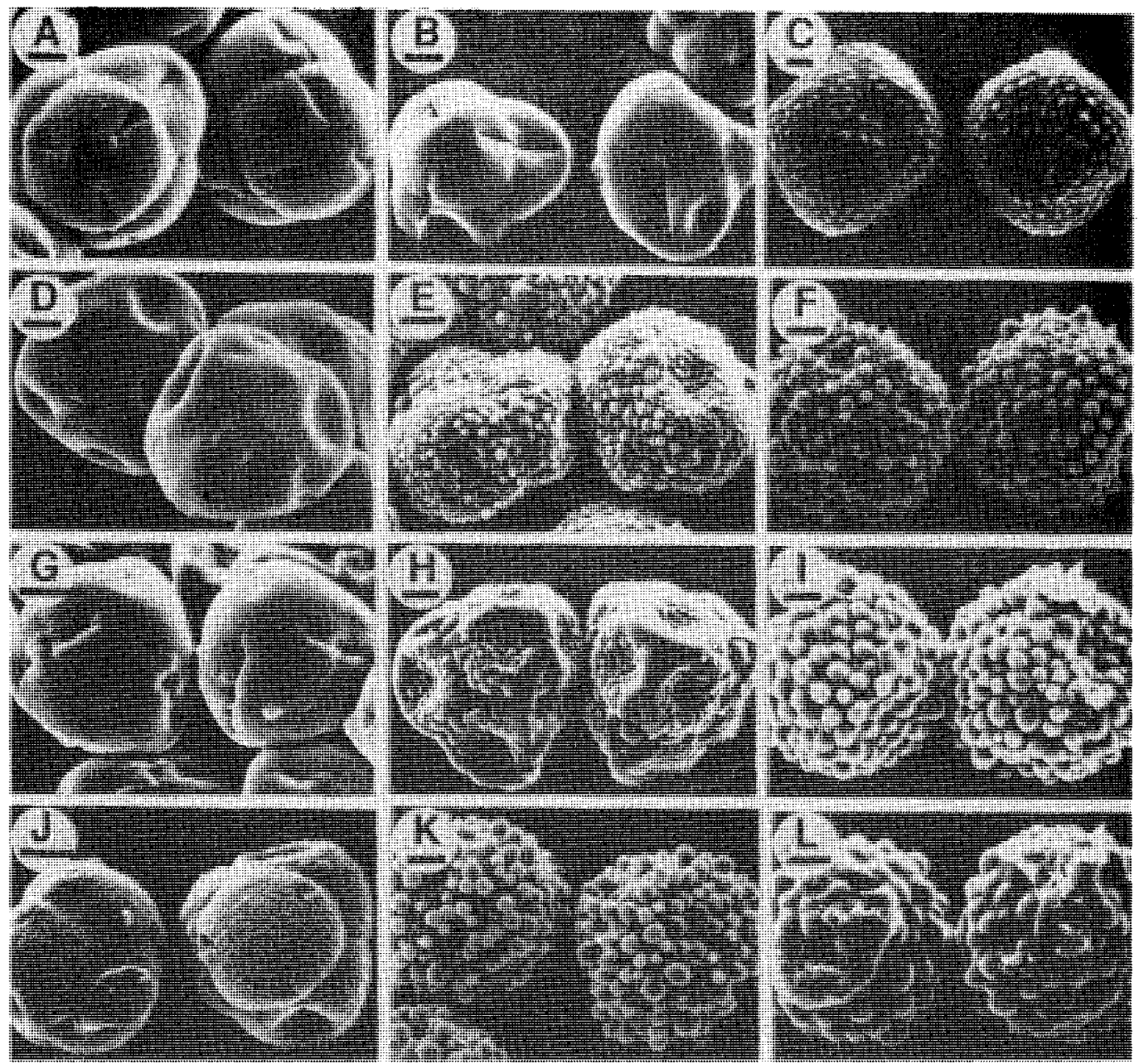

PLATE 1

Variation in the pollen surface ornamentation of Epacris Cav. Scale bar $=10 \mu \mathrm{m}$. (A) E. calvertiana (smooth)both varieties, $(B)$ E. obtusifolia - type A (smooth), (C) E. obtusifolia - type B (small warts), (D) E. tasmanica $($ smooth), $(E)$ E. virgata (irregular warts), $(F)$ E. exserta (irregular warts), $(G)$ E. microphylla (smooth), $(H)$ E. barbata (smooth with wrinkles), (I) E. crassifolia (large warts), (I) E. navicularis (smooth with rough surface), $(K)$ E. grandis (large irregular warts), (L) E. muelleri (convoluted warts).

E. impressa, E. gunnii and E. microphylla. In other species, surface features (other than discrete warts) may be evident. Thus the surface is rugulate and appears wrinkled in $E$. barbata, $E$. tasmanica and $E$. serpyllifolia, while in $E$. navicularis it is overall roughened. In the warted pollen there is variation both in the size and density of the processes. The largest warts occur in E. grandis and in E. crassifolia. A range of wart sizes occurs in $E$. acuminata and in E. virgata and related species. Epacris obtusifolia-type B pollen has grains with small and relatively sparse warts. In two taxa E. muelleri and E. heteronema-type B, the warts appear to merge forming a convoluted surface. Plate 1 shows a selection of pollen grains to illustrate the variation. 


\section{DISCUSSION}

Our results confirm the observations of Matthews regarding 14 species with psilate (smooth) ektexine of the pollen grains. An additional 13 taxa are reported by us as belonging to this category (appendix 1). Three taxa in this group warrant comment.

(1) E. serpyllifolia, listed by Matthews as a "warted" species, occurs as a low scrambling shrub on the montane plateaux of Tasmania and Victoria. In Tasmania it sometimes extends into sub-alpine forest as an erect medium-tall shrub exceeding $3 \mathrm{~m}$ in height. Despite this habitat-related variation in habit, the species has consistent leaf and floral morphology and the pollen of specimens obtained from a variety of sources was uniformly smooth. Matthews' specimen ostensibly was collected from the Mt Kosciusko plateau. However, Costin et al. (1979) do not list E. serpyllifolia as occurring on Mt Kosciusko, so it is most likely that Matthews' specimen was misidentified and probably confused with the more recently described $E$. glacialis, which has warted pollen (appendix 1).

(2) E. heteronema: Matthews' specimen of this species was reported as collected from Eaglehawk Neck, Tasmania. We believe this to be a specimen misidentification. Ecologically the area is quite atypical of that normally occupied by E. heteronema, and there are no other records, past or recent, of its occurrence there. His specimen was possibly confused with $E$. virgata which has a reasonably widespread distribution on the Tasman Peninsula (see below). The pollen of $E$. virgata, like Matthews' specimen, is warted. We are currently studying two taxa within $E$. heteronema. E. heteronematype A, which occurs in some coastal heathland and wet scrub areas in southwestern Tasmania, e.g. around Southport, has glabrous bracts and sepals and smooth pollen. E. heteronema-type B, which occurs widely in southwestern Tasmania in sedgeland-heathland vegetation and in sclerophyll forest at both low and high altitudes, has hirsute bracts and sepals and warted pollen. A decision on the taxonomic status of these two taxa will be deferred until later in the revision of the genus.

(3) E. obtusifolia is widespread in swampy sites in Tasmania, Victoria and the eastern seaboard of New South Wales and southeastern Queensland (E. obtusifolia-type A). Its pollen is uniformly smooth. However, in the coastal sandstone region south of Sydney a form occurs which is conspicuously larger than usual, and shows minor differences in floral morphology, E. obtusifolia-type B. This form has pollen with small warts (pl. 1C) and is probably the taxon which Matthews examined. His specimen was collected from nearby Jervis Bay. Additional collections and further study of type B are required before further comment can be made on its taxonomic status.

Matthews lists nine species with a warted ektexine. We confirm eight of these (including E. heteronematype $\mathrm{B}$ and E. obtusifolia-type B) and add eight other taxa including $E$. acuminata from Matthews' intermediate class. In our investigations, pollen of E. acuminata has ektexine processes of variable size just as in several other taxa within this group, e.g. E. virgata.

Variation in the ektexine warting of pollen grains has supported some taxonomic decisions which we have made during our study of the genus.

(1) The data confirm that certain southern Tasmanian populations previously considered to be part of $E$. tasmanica (sensu lato) really belong to E. virgata (Crowden \& Menadue 1990). E. virgata (pl. 1E), like its close relatives E. stuartii, E. exserta (sensu stricto), and the undescribed taxa from Serpentine Hill and Mt Cameron, has warted pollen. The pollen from E. tasmanica (sensu stricto) is smooth (pl. 1D).

(2) Several species, all with exserted anthers, which occupy riverine habitats in Tasmania, frequently are confused and "lumped" under E. exserta. However, E. exserta (sensu stricto), which can be clearly defined by a suite of morphological characters, has warted pollen (pl. 1F). The other riverine taxa in this group have smooth pollen. They may be separated from each other on morphological grounds into two species, E. tasmanica (sensu stricto) and an undescribed species ("Union Bridge") from the Mersey and Meander Rivers in northern Tasmania.

(3) E. barbata has restricted occurrence on the granitic soils of Freycinet Peninsula. A form with minor morphological differences but a later flowering period (November-December compared with AugustSeptember) is found on sea-facing coastal cliffs in the same region. However, both taxa have the same pollen ornamentation, supporting our decision, based on morphometric studies, to include the cliff-face taxon within $E$. barbata.

Smith-White (1959) and Franks \& Watson (1963) have shown there is considerable diversity of pollen types between genera of the tribe Stypheliae (Epacridaceae), while pollen of the tribe Epacrideae are more homogeneous. A thorough between-genera investigation of ektexine sculpturing in the Epacridaceae has not been carried out. Our own incomplete examination of Sprengelia and Richea species indicates that the pollens of most of these species are 
smooth. However, Matthews' data suggest an intergeneric dfference between Epacris and Rupicola (i.e. E. apiculata).

The differences in pollen surface sculpturing reported by Matthews and by us are at the intrageneric level. There are no formal sub-generic divisions within the genus Epacris, although certain groups of species do show loose relationships, listed below, in respect of the ektexine sculpturing of their pollen grains.

(1) All eight taxa in which the anthers are wholly exserted beyond the corolla tube have warted pollen (E. acuminata, E. exserta, E. glacialis, E. grandis, E. stuartij, E. virgata, "Mt Andrew", "Mt Cameron" and "Serpentine Hill"). Taxa with anthers partially exserted or enclosed have smooth pollen.

(2) Eight of ten taxa in which the corolla tube clearly exceeds the sepals in length have smooth pollen. The exceptions are E. crassifolia and E. obtusifolia-type B.

(3) Species with generally short, campanulate tubes with filaments which project the anthers towards the centre of the throat all have smooth pollen (E. gunnii, E. microphylla, E. breviflora, E. navicularis and E. petrophila).
However, the main practical usefulness of pollen sculpturing in Epacris has been to aid in the delimitation of taxa which typically have overlapping morphological features.

\section{REFERENCES}

Costin, A.B., Gray, C.M., Totterdell, C.J. \& Wimbush, D.J., 1979: KOSCIUSKO ALPINE FLORA. CSIRO and Collins Australia, Melbourne.

Crowden, R.K. \& Menadue, Y., 1990: Morphometric analysis of variation in the Epacris tasmanica complex (Epacridaceac). Aust. Syst. Bot. 3:253-264.

FranKS, J.W. \& W ATSON, L., 1963: The pollen morphology of some critical Ericales. Pollen et Spores 5: 51-68.

MatTHEws, J.M., 1965: Warted pollen grains of Epacridaceae. Nature 208: 803-804.

Matrhews, J.M., 1966: Some descriptions of the pollen morphology of Epacris Forst. emend. Cav. Pollen et Spores 8: 461-478.

McGlone, M.S., 1978: Pollen wall structure of the New Zealand species of Epacris (Epacridaceae). NZJ.Bot. 16: 83-89.

Smith-White, S., 1959: Pollen development patterns in the Epacridaceae. Proc. Linn. Soc. NSW 84: 8-35.

$$
\text { (accepted } 10 \text { August 1990) }
$$

Y. Menadue and R.K. Crowden

Department of Plant Science, University of Tasmania, GPO

Box 252C, Hobart, Tasmania, Australia 7001

\section{APPENDIX 1 \\ Ektexine Ornamentation of Pollen Grains in Epacris Cav. (Epacridaceae)*}

\section{Psilate (smooth) ektexine}

E. apsleyensis R.K. Crowden (2)

E. barbata Melville (7)

E. breviflora Stapf (1)

E. calvertiana $\mathrm{F}$. Muell. var. calvertiana (2)

E. calvertiana F. Muell. var. versicolor Maiden et Betche (3)

E. coriaceae A. Cunn. ex DC (2)

E. corymbiflora Hook. f. (2)

E. curtisiae S.J. Jarman (3)

E. gunnii Hook. f. (2)

E. hamiltonii Maiden et Betche (2)

E. heteronema Labill. - type A (8)

E. impressa Labill. (7)

E. lanuginosa Labill. (4)

E. longiflora Cav. (3) .

E. microphylla R. Br. (4)

E. mucronulata R. Br. (5)

E. navicularis S.J. Jarman (2)

E. obtusifolia Sm. - type A (2)

E. paludosa R. Br. (1)

E. petrophila Hook. f. (3)

E. pulchella Cav. (7)

E. purpurascens R. Br. var. onosmiflora Maiden et Betche (4)
E. reclinata A. Cunn. ex. Benth. (2)

E. robusta Benth. (1)

E. serpyllifolia $\mathrm{R}$. Br. (9)

E. tasmanica W.M. Curtis (7)

E. "Union Bridge" (7)

\section{Verrucate (warted) ektexine}

E. acuminata Benth. (3)

E. crassifolia R. Br. (2)

E. exserta R. Br. (3)

E. glacialis M. Gray (3)

E. grandis R.K. Crowden (3)

E. heteronema Labill. - type B (7)

E. marginata Melville (4)

E. muelleri Sond. (2)

E. myrtifolia Labill. (6)

E. obtusifolia Sm, - type B (2)

E. rigida Sieb. ex Spreng. (2)

E. stuartii Stapf (2)

E. virgata Hook. f. (9)

E. "Mt Cameron" (1)

E. "Mt Andrew" (1)

E. "Serpentine Hill" (2)

* Numbers of specimens examined shown in parentheses. 


\section{APPENDIX 2}

\section{Specimens Examined for Pollen Sculpturing*}

Epacris acuminata (HO 115368)

E. apsleyensis (HO 115369)

E. barbata P. Collier 629 (HO)

E. breviflora (HO 115364)

E. calvertiana var. calvertiana (HO 115372)

E. calvertiana var. versicolor (HO 123225)

E. coriaceae (HO 115373)

E. corymbiflora (HO 115353)

E. crassifolia (HO 115363)

E. curtisiae (HO 1190770)

E. exserta ( $\mathrm{HO} 115361)$

E. glacialis (HO 1180030)

E. grandis A. Moscal $66(\mathrm{HO})$

E. gunnii (HO 115351)

E. hamiltonii E.F. Constable (NSW 47488)

E. heteronema-type A (HO 115367)

E. heteronema-type B (HO 115359)

E. impressa (HO 115350)

E. lanuginosa (HO 115344)

E. Longiflora ( $\mathrm{HO} 115357$ )

E. marginata (HO 115360)

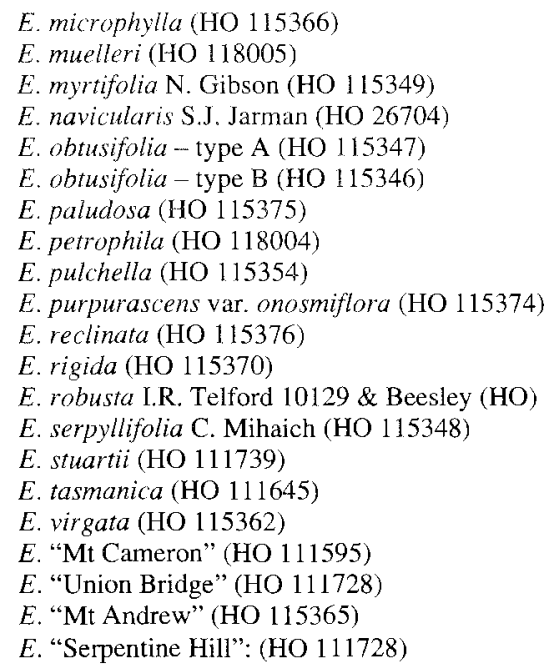

* All specimens collected by authors unless stated otherwise. 